\title{
Kolorektalkreft kan forebygges
}

\section{Fjerning av adenomatøse polypper ved koloskopi reduserer risikoen for å dø av kolorektalkreft, viser en ny studie.}

Pasienter ble inkludert i en amerikansk kohortstudie etter henvisning til koloskopi pga. tidligere undersøkelsesfunn, symptomer eller familiehistorie med kolorektalkreft (1). Pasientene ble delt $\mathrm{i}$ to grupper avhengig av om de hadde adenomatøse polypper eller kun ikke-adenomatøse polypper, og alle polypper ble fjernet. Risiko for å dø av kolorektalkreft i disse to gruppene ble sammenliknet med estimert risiko i normalbefolkningen.

Blant pasientene med adenomatøse polypper $(\mathrm{n}=2062$, median oppfølgingstid 15,8 år) døde 12 av kolorektal kreft. Det var en $53 \%$ reduksjon sammenliknet med et

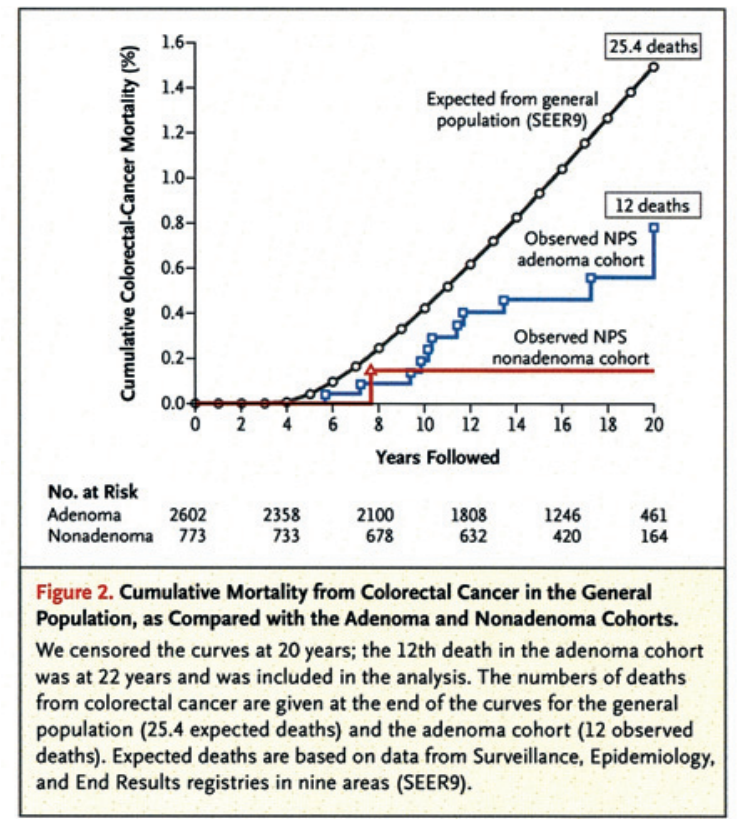

Gjengitt med tillatelse fra The New England Journal of Medicine (1) estimat på 25,4 tilsvarende dødsfall i normalbefolkningen. De første ti årene etter inklusjon hadde pasientene med adenømatøse polypper tilnærmet lik risiko for å dø av kolorektalkreft $(0,19 \%)$ som pasientene med ikke-adenomatøse polypper $(0,15 \%)$.

- Studien tyder på at fjerning av tarmpolypper forhindrer kreftutvikling og død, sier professor Kjetil Søreide ved Kirurgisk avdeling, Stavanger universitetssjukehus. Forskerne angir omtrent en halvering av mortaliteten, men dette er ganske grov estimering fordi antall pasienter er relativt lavt.

De norske legene Michael Bretthauer og Mette Kalager påpeker $\mathrm{i}$ en ledsagende lederartikkel at oppsettet ikke er overførbart til en screeningsituasjon, bl.a. fordi pasientene var henvist pga. symptomer (2). Dessuten er den generelle befolkningen blitt eldre og friskere, og det har skjedd store fremskritt i bruken av bildediagnostikk, noe som har endret kurasjonsrater for kolorektalkreft. Studien viser at fjerning av polypper virker, men det er usikkert om effekten vil være like god i et randomisert screeningprogram, sier Søreide.

\section{Merete Kile Holtermann}

merete.holtermann@legeforeningen.no

Tidsskriftet

\section{Litteratur}

1. Zauber AG, Winawer SJ, O'Brien MJ et al. Colonoscopic polypectomy and long-term prevention of colorectal-cancer deaths. N Engl J Med 2012; 366 : 687-96.

2. Bretthauer M, Kalager M. Colonoscopy as a triage screening test. N Engl J Med 2012; 366: 759-60.

\section{HDAC9-genet spiller en rolle ved hjerneslag}

\section{Genomvide assosiasjonsanalyser har identifisert HDAC9-varianter som påvirker risikoen for utvikling av hjerneinfarkt.}

Hjerneslag er en av de tre vanligste dødsårsakene $i$ vestlige land. Man vet en del om risikofaktorer, bl.a. hypertensjon, men bakenforliggende årsaker er lite kjent. Hjerneslag inndeles gjerne i storkarsykdom, småkarsykdom og kardioembolisk sykdom, og risikofaktorene er noe ulike. Tvillingstudier tyder på en viss arvelighet.

En internasjonal forskningsgruppe har nå utført genomvide assosiasjonsstudier, såkalte GWAS-studier, der de sammenliknet 3548 pasienter med 5972 kontrollpersoner (1). Replikasjon av interessante genområder ble utført på prøver fra 5859 pasienter og 6281 kontrollpersoner. Gruppen bekreftet tidligere funn og identifiserte $H D A C 9$ som assosiert med storkarsykdom. HDAC9 koder for histondeacetylase 9. Genet er lokalisert på kromosomarm 7p. Dette funnet ble så bekreftet $i$ en populasjon med 735 pasienter og 28583 kontrollpersoner.

- Denne studien viste en assosiasjon mellom varianter i $H D A C$ 9-genet og storkarsykdom, dvs. aterosklerose. En slik assosiasjon er potensielt viktig, men har liten relevans for kartlegging av grunnsykdommen hos den enkelte slagpasienten, sier Lars Thomassen, overlege og professor ved Haukeland universitetssykehus. - Pasienter med ukjent årsak eller flere mulige årsaker ble ikke tatt med. De fleste genetiske risikofaktorene vil kun vise en liten oddsratio og har minimal positiv prediktiv verdi, sier han.
- Forfatterne påviste også at det forelå en genetisk heterogenitet for forskjellige subgrupper av hjerneslag, og konkluderte med at denne genetiske heterogeniteten sannsynligvis gjenspeiler den patofysiologiske heterogeniteten bak hjerneinfarktene. Deres anbefaling er å vurdere forskjellige subgrupper av hjerneslag hver for seg, både i forskning og i klinisk virksomhet. Denne konklusjonen kan en kliniker lett si seg enig i, sier Thomassen.

\section{Åslaug Helland \\ aslaug.helland@gmail.com \\ Tidsskriftet}

Litteratur

1. Bellenguez C, Bevan S, Gschwendtner A et al Genome-wide association study identifies a variant in HDAC9 associated with large vessel ischemic stroke. Nat Genet 2012; 44: 328-33. 